\title{
The Effectiveness of Online Game on Students Vocabulary Enrichment
}

\author{
Yelia Yelia ${ }^{1, *}$ Dony Efriza ${ }^{2}$ \\ 1,2 Universitas Jambi, Jambi, Indonesia \\ ${ }^{*}$ Corresponding author. Email: davizayelia@gmail.com
}

\begin{abstract}
This article tells readers about the effectiveness of using online game on students' English vocabulary enrichment. This is a quasi-experimental research which gives different treatment to experimental class and control class. Online game was used in the experimental class and conventional teaching media was used in the control class. The populations of the study were all the second semester students of non-English Department of the Faculty of Teacher Training and Education, University of Jambi. The samples were taken by using cluster sampling technique. Test and non-test were used as the instruments of collecting data. The results of the study show that: (1) the students who were taught by using online game had better result on English vocabulary enrichment than the students who were taught by using conventional teaching media. (2) The students who were taught by using online game gave positive response to online game as a various media in learning English vocabulary, so this media can motivate the students for learning vocabulary in the class and out of the class.
\end{abstract}

Keywords: Effectiveness, Online Game, Vocabulary Enrichment.

\section{INTRODUCTION}

One of the basic part for learning language is vocabulary. Without vocabulary, communication will not be happened well. Furthermore, the students will difficult to operate their electronic devices and access information. Vocabulary is all the list of words of a language that has been acquired by a particular person and understood by others. By enriching vocabulary, it is a key for success to speak well, composed a good writing, and also comprehend the language well so language learners have to enrich their vocabulary by around 1000 words a year [1]. It is in line with Clark, D.M, \& Fairburn C.G. [2] states that the language learners must enrich their vocabulary 1000-1500 words every year. Vocabulary is all the words of a language or the words used by a particular person. Therefore, appropriate strategy in teaching vocabulary is needed.

The basic element that should be mastered by language learners is vocabulary. By enriching vocabulary, the language learners can be easy for achieving all language skills in a language. Teaching vocabulary is a basic task in teaching language because it is related to all language skills. Based on the observation, the students who take English subject on online meeting, for non-English department, at the Faculty of Teacher Training and Education of University of Jambi still have lack of vocabulary enrichment. Besides that, the students did not pay attention when teaching learning vocabulary process happened so it impacts on their English language skills. Riahipour \& Saba [3] states traditional activities such as repetition of words, memorization of long vocabulary lists, derivations, translation, fill in the blank exercises are kinds of boring activities for students.

Language learners usually have some problems for enriching their vocabulary and the problems are; they do not know the context of word usage, cannot recognize the meaning of each word, not able to listen the English words from speakers, cannot compose their writing task successfully, and get difficulty to communicate effectively in English. The other problem that faced by the students is they should learn from home in this covid -19 pandemic era. Hopely, they can learn optimally from their home, so appropriate strategy and media are needed to solve those problems.

Covid-19 pandemic has changed the way of life of human being in the world, especially for the students which they should do their activities from home. All of the students must learn from home and all of the lecturer must teach from home and one way that they can do is 
online teaching and learning. Besides that, most of the lecturer still use most common online teaching media, such as: WA, Telegram, and e-learning which only provide many documents that can be make boring atmosphere on online teaching learning activity.

Teaching English needs appropriate strategy and good media in the teaching and learning activity. Those aspecs can be made the students not bored and they become active in the teaching learning activity. Nugrahani [4] states motivation in learning for the students can be built by using appropriate media in teaching learning process because the media play an active role in learning. It is in line with Oyedele [5] states the provision and effective use of media is what distinguishes a superior school or college from an inferior one, and an effective teacher from an in effective one. So, a good media is needed to achieve the students ability.

One of the media teaching and learning on online meeting is online game. Online game is a technology which can be connected to multy player. An online game is a game which can be played by using internet connection or any other network device available. Online games are ubiquitous on modern gaming platforms, including PCs, consoles and mobile devices.

In this research, online game was used as a media technology to enrich students' vocabulary on online meeting. Online game was created through 2 platforms, they are: superteacher.com and kahoot.com which can be seen on the http://sites.google.com/view/mkduengunja/home/vocab ulary-building. It makes students more interested in learning process. Of course, by using online game, it helps the students to memorize the words, helps the lecturer to increase students' interest and motivation to enrich their vocabulary. Based on those reasons, it is interested to know the effectiveness of online game on students vocabulary enrichment.

\section{METHOD}

An experimental study was used for this study. According to Ary and Jacobs [6] an experiment study is a specific investigation in which the researcher manipulates one or more independent variables, controls any other relevant variables, and observes the effect of the manipulations on the dependent variable(s). This study has one dependend variable (online game) and one independed variable (vocabulary). In this experimental study, there are two groups, they are: control group and experiment group, and they were given different treatment in doing the research.

The population in this study was all of the first semeseter students on the Faculty of Teacher Training and Education (University of Jambi) and two classes were taken to be sample of the research. According to Salkind [7] cluster is groups that appear to gather in which units of individual are selected rather than individual themselves. Then, cluster random sampling was used to choose experiment and control class. The first semester students, 59 students, who learn English subject on Civic Education Study Program were taken as the sample of the research which divided into two classes. Then, vocabulary test, which have been developed by four indicators; synonyms, antonyms, verbal classification, and analogies and which has been in validation and reliability, was used as pre-test and posttest. The last, questionnaire was distributed for knowing the response of the students on vocabulary online game.

Pre-test was given to the students on the first meeting to know students' initial abilities towards vocabulary after that the experimental group was given new treatment that was online game in vocabulary teaching learning process and the control group was given common online teaching method that used by the English lecturer.

At the end of the online meeting, post-test and questionnaire were distrubuted for the students. Prerequiste anaylis was analysed to know normality and homogeneity for both of clasess. Further, the hyphothesis testing was described into:

H0 : the students who are taught by Online Game get same result on vocabulary than those who are taught by convensional online teaching learning media (WA, Telegram, Zoom and eLearning)

H1 : the students who are taught by Online Game get better result on vocabulary than those who are taught by convensional online teaching learning media (WA, Telegram, Zoom, and e- Learning)

The hypothesis of the research was analyzed by using t- test.

\section{FINDINGS AND DISCUSSION}

The average score of both tests (pre and post test) of this study can be seen from the table bellow:

Table 1. Average Vocabulary Score

\begin{tabular}{|l|c|c|}
\hline Test & Experiment Class & Control Class \\
\hline Pre Test & 25,66 & 24,77 \\
\hline Post Test & 65,00 & 44,40 \\
\hline
\end{tabular}

Based on the data above, pre-test showed that experiment class and control class have the same ability of vocabulary. After giving a treatment on the experiment class, it can be seen that post test of experiment class got 65,00 vocabulary average score and 44,40 for control class. In the other hand the average score of experiment class was higher than control class. On the other hand, the experiment class has significant average score of vocabulary than control class. 
Prerequisite analysis was done by using two kinds of analysis, they are: normality and homogeneity testing. Based on the analysis output of normality by using liliefors test shown that control and experiment class were distributed normal. It can be seen on the table below:

Table 2. Normality Testing

\begin{tabular}{|l|l|l|l|l|}
\hline Class & $\mathbf{N}$ & Lobserved & Ltable & Note \\
\hline Experimental & 28 & 0.115 & 0.173 & $\begin{array}{l}\mathrm{L}_{\mathrm{o}}<\mathrm{L}_{\mathrm{t}} \\
\text { Normal }\end{array}$ \\
\hline Control & 30 & 0.079 & 0.159 & $\begin{array}{l}\mathrm{L}_{\mathrm{o}}<\mathrm{L}_{\mathrm{t}} \\
\text { Normal }\end{array}$ \\
\hline
\end{tabular}

Further, homogeneity testing output of control and experiment class shown that, both of class are homogeneity. On the other hand, there is no difference in variance of vocabulary data for both of clasess.

Table 3. Homogeneity Testing

\begin{tabular}{|l|l|l|l|}
\hline Variable & Fobserved & Ftable & Conclusion \\
\hline Vocabulary & 1.20 & 3.31 & Homogenous \\
\hline
\end{tabular}

Based on the statistical analysis of post- test on this study found that vocabulary of students who are taught by online game is better than the students' vocabulary who are taught by convetional online teaching. It can be seen from t-test of this study below:

Table 4. T-Test Result

\begin{tabular}{|c|c|}
\hline $\mathbf{t}_{\text {observed }}$ & $\mathbf{t}_{\text {table }}$ \\
\hline 4.395 & 1.69 \\
\hline
\end{tabular}

Based on the table 4, it can be seen that tobserved > ttable. It means that, $\mathrm{HO}$ is rejected.

The mean score of experimental class which taught by online game is higher than control class which taught by conventional online teaching method. It means that, online games can enrich students' vocabulary. Moreover, the result of the hypothesis which explain that tobserved $>$ ttable. Briefly, online games give significant effect toward students' vocabulary. This result is in line with the research which conducted by Rahayu and Riska [8] was found that game is needed for the effectiveness of learning vocabulary.

Besides that, the quantitative data taken from the questionnaire also showed that students gave positive responses on vocabulary online game. It can be shown on table bellow:

Table 5. Response of the Students on Online Game

\begin{tabular}{|l|l|l|}
\hline Total Score & \multicolumn{1}{l}{ Average Score } & \multicolumn{1}{l|}{ Percentage } \\
\hline $\mathbf{1 . 3 3 5}$ & 4,76 & $95,4 \%$ \\
\hline
\end{tabular}

It can be seen that percentage of the students' respons on the online game is $95,4 \%$. It means that the students give a very positive response on the online game. According to Sumardi and Muamaroh [9] positive perception or response enables each student to achieve the predetermined instructional objectives much more easily as well. It is in line with [10] Kosar who states that students' with positive responses embark to promote students' learning strategies and make them success to achieve the desired instructional objectives. Briefly, online game can be a solution for enriching students' vocabulary. The students looked enjoyed on online class and the media was very helpfull for the students to improve their vocabulary.

\section{CONCLUSION}

From the research findings and discussion above, it can be concluded that online game is an effective way to enrich students' vocabulary. It can give better result on students' vocabulary then convensional online teaching method. On the other hand, online game is very accapeted by the students as various online media for teaching and learning method. Besides that, it also can be applied on the other subject as various media and strategy on online meeting. Indirectly, this media can motivate students on online learning activities.

\section{SUGGESTION}

Based on the findings and conclusion above, it can be taken some suggstion as follows:

1) It is suggested that English teachers or lecturers use online games as a variation of teaching vocabulary

2) This media gives positif effect for the students for enrhicing their vocabulary and the students can practice their vocabulary wherever they are so it can be an effective and eficient way to increase their vocabulary.

3) It is also suggested for further researcher to develop this research for other population, language skills and kinds of online games in order to get the information and empiric data

\section{REFERENCES}

[1] P. National, 1990. Teaching and Learning Vocabulary. New York: Newbury House Wallace,

[2] D.M. Clark, \& C.G. Fairburn 1997. Science and Practice of Cognitive Behavior Therapy. Oxford University Press

[3] P. Riahipour, \& Z. Saba, 2012. ESP vocabulary instruction: investigating the effect of usinga game oriented teaching method for learners of English for nursing. Journal of Language Teaching and Research 3(6). 
[4] F. Nugrahani, 2017. The Development of FilmBased Literary Materials Which Support Character Education. Cakrawala Pendidikan 36(3), 472-486. doi:10.21831/ cp.v36i3.14219.

[5] S. Oyedele, J. Rwambiwa, \& A. Mamvuto, 2013. Using Educational media and technology in teaching and learning processes: a caseof trainee teachers at Africa University. Academic Research International Journal 4(1). Retrieved 4 September 2017, from http://www.savap.org.pk/ jour nals/ARInt.4(1)/2013(4.1-30).pdf.

[6] Ary, D., and Jacobs. 2002. Introduction to Research Education. New York: Holt, Rhienthart and Winston

[7] J. N. Salkind, 1991. Exploring Research. London: Macmillan Publishing Company.

[8] A.W. Rahayu, \& Y. R. Suastika (2018). Pengembangan Media Pembelajaran Game Kosakata Bahasa Inggris. Cakrawala Pendidikan 37 (1), 85-96.

[9] Sumardi \& Muamaroh. (2020). Edmodo Impacts: Mediating Digital Class and Assessment in English Language Teaching. Cakrawala Pendidikan 39 (2), 319-331. doi:10.21831/cp.v39i2.30065

[10] G. Kosar, (2016, 14-17 April). A study of EFL instructors' perceptions of blended learning. Paper presented at International Conference on Teaching and Learning English as an Additional Language (GlobELT),

Turkey. https://www.sciencedirect.com/science/article/pii/ S1877042816313337. 